〈proceedings〉

当院における抗菌薬適正使用支援 Antimicrobial Stewardship（AS）以外の AMR アクションプランの実践について

\author{
築地 淳 ${ }^{1)} \cdot$ 河原 春代 ${ }^{1)} \cdot$ 比嘉 令子 ${ }^{1)} \cdot$ 杉山 嘉史 ${ }^{1)}$ \\ 辻田佳小里 ${ }^{1)} \cdot$ 木田沙緒里 ${ }^{1)} \cdot$ 椙山聡一郎 ${ }^{1)} \cdot$ 清水 博之 ${ }^{1,2}$
}

\title{
Well-balanced Practice of the AMR Action Plan in Yokohama City University Medical Center
}

\author{
Jun Tsukiji ${ }^{1}$, Haruyo KaWAharA ${ }^{1)}$, Ryoko HigA ${ }^{1)}$, Yoshifumi SugrYama ${ }^{1}$, \\ Kaori TsujiTA $^{1)}$, Saori KIDA ${ }^{1)}$, Soichiro SugIYAmA ${ }^{1)}$ and Hiroyuki ShIMIZU ${ }^{1,2)}$ \\ 1) Department of Prevention and Infection Control, Yokohama City University Medical Center, \\ ${ }^{2)}$ Department of Clinical Laboratory Medicine, Fujisawa City Hospital
}

(2019 年 9 月 12 日受付 $\cdot 2019$ 年 10 月 3 日受理)

\begin{abstract}
要 旨
国際的に深刻な健康危機をもたらしている薬剤耐性菌問題に対して策定された薬剤耐性（AMR） アクションプランに基づく対策実施が医療現場において重要な課題となっている. アクションプラ ンを構成する教育・啓蒙, 動向調査・監視, 感染予防・管理, 抗微生物剂の適正使用, が市中病院 における重点的な活動目標であるが，抗菌薬適正使用支援 Antimicrobial Stewardship（AS）以外 の主眼をおいた我々の施設における実践について紹介する.
\end{abstract}

Key words : 薬剂耐性, AMR, AMR アクションプラン

\section{はじめに}

AMR アクションプランは薬剤耐性（AMR：Antimicrobial Resistance) により深刻化する世界的な危機に 対して, 2016 年 4 月に取りまとめられ ${ }^{1)}$, 伊勢志摩サミッ トにおいて 2020 年までの成果達成を目標として揭げら れたもので,（1）啓発・教育，（2）サーベイランス・モ ニタリング (動向調査・監視)，（3）感染予防・管理，（4） 抗微生物剂の適正使用, (5) 研究開発・創薬, (6) 国際 協力・グローバルヘルスアーキテクチュア, 等の活動目 標により構成されている. 一般の市中病院における活動 としては（1）〜（4）が中心となり, 特に今般の抗菌薬 の供給制限（出荷調整）による混乱が長期化・深刻化す るにつれて, 抗菌薬適正使用以外の活動の重要性が相対 的に高まっていると言えよう.

我々の所属施設は横浜市最大の医療機関（病床数 726） であり, 首都圈でも屈指の高度救命救急センター（応需 率 98\%), 周産期センターを有する市中病院である (2018

1) 横浜市立大学附属市民総合医療センター感染制御部，2)藤沢市民 病院臨床検査科
年度の手術件数 8698 件/年, 外来患者数 1998 名/日). 院内においてアクションプラン推進の中心となる感染制 御部は, 所属医師 2 名 (専任), 看護師 1 名 (専従) を 核として専任の薬剤師と臨床検査技師各 1 名を加えた計 5 名で構成され，Antimicrobial Stewardship（AS）な どの AST 活動における主役を演じている. 病院規模に 対してASTとしては標準的なものと言えよう.

我々はAMR アクションプランの成果実現のための薬 剂耐性菌抑制の第一歩は, 治療対象がきちんと「診断」 されること，「正しい診断」に立脚した合理的な治療が 施されていること，を重要視している．単に見様見真似 でASTを編成し体裁を整えるだけでは, 感染加算獲得 のための言わばアリバイ作りと見做されても仕方がない. 例えば，診療医が正しい診断を導けるように臨床検査技 師が微生物情報を現場に巧く伝える工夫と努力が必要で あるし, ICN から病棟看護師に, 適切な血培のために 皮膚消毒が適切に実施されるように, 教育し協力を得る ことなども大切である. さらに, 診断確定後は薬剤師か らタイムリーに最適治療薬や TDM 実施の助言をする, 等々, ASTメンバーの職種それぞれの得意分野を生か 
して診療科をしっかりサポートし続けるという姿勢が一 貫していることが，院内における診療科との信頼関係を 䤑成し, ひいてはアクションプランを推進する上で大切 な基盤となる.

AMR アクションプランにおける前記（4）の活動目 標の中心である AS が重要であることは論を待たないが, 本稿では AS 以外にも焦点をあてた活動を中心に紹介し たい.

\section{（1）啓発・教育}

\section{（イ）国民に対する薬剤耐性の知識・理解に関する普 及・啓発活動の推進}

我々にとって「国民」とは患者，面会者，職員のこと である. 当院では約 2000 名の職員が従事している．掲 示用ポスターなどのツールは AMR 臨床リファレンスセ ンター等が公開し利用できるものが豊富にある。しかし， 単なる形式的なポスター貼付のみでは期待される効果は 不十分である。これを目にした者が意義を理解し，「しっ かり手洗いするようになる」というアウトカムを導くた めには, 例えば, インフルエンザ流行時期と連動させて 世間の関心の高まりに合わせてタイムリーに集中的に行 う，等とすると，より効果も高まるであろう。 あるいは, 全職員に対して e-Learning を用いれば, 病院全体で耐 性菌の感染機会を増やさないために取り組むことの重要 性を説くことができる. ICT ニュース（ポスター貼付 および院内メールで一齐配信）も同様の意義がある．特 に冬季感染症流行期には手指衛生の周知を反復すること で，職員が予防行動を起こすための動機づけとなるアウ トカムを目指している.さらに，少人数で活動している 我々にとり，職員から電話や文面で送られてくる質問に 対して, 迅速丁寧に筋道立てて説明していくことも信頼 醸成のために大切であり，感染対策活動の仲間として, 意識の高い理解者を引き入れるチャンスと捉えるとよい.

\section{（口）関連分野の専門職に対する教育・研修の推進}

若手医師・看護師などコメディカルを主な対象とした 講演会, 血培講習会, 臨床実習生 (医学部生・看護学部 生）に対する教育などがこれに該当し，次世代の人材育 成のための重要な活動である.

最近では, 以前と比較して抗菌薬投与前の血液培養実 施率および採取時の複数セット実施率は上昇してきてお り，「適正化が浸透」してきたかのようである。しかし ながら, 反省すべき最近の傾向の一つに, いきなり広域 抗菌薬を開始するための免罪符かのように血培採取自体 が目的化しているようなケース（例えば，免疫不全者が 発熱すれば血培実施しさえすれば即カルバペネム系で開 始，といった具合）が目立つようになった．あるいは AST 活動が院内で認知されるにつれて, 血培採取後の 選択薬は感染制御部に全てを託す（わかりやすく換言す
れば自分で考えずに放り投げる）といった安易なケース が増加しており, 我々もそのような事例の抗菌薬を狭域 化することが活動の真髄であるかのように錯覚している きらいがある。しかし，AST 活動の原点に返ると，診 療医が血培実施を思い立つ契機となった発熱なり高炎症 反応なりの原因について, 彼らが正しく「診断」を下し, 診断に立脚した適切な治療選択ができる状態に誘うこと が重要な使命なのである。つまり「診断支援」である.

我々は, 診療医が少なくとも感染症に関して適切な診 断に基づいて診療するための支援として, First touch で発熱患者と接する研修医・若手医師を集めて, まだ彼 らの着想力が柔軟なうちに, 抗菌薬（抗微生物薬）は発 熱の原因となる病原菌と感染臓器が同時に決定されて初 めて最適な選択が可能であることを薬剤師から，あるい は病原菌決定のための培養検体の採取法, 結果の解釈に ついて臨床検査技師からも講演を行っている．また，看 護師の理解を深め協力を得るために, 不必要な治療機会 を生まないために感染経路別予防策の実演も含めた勉強 会・院内講演なども頻繁に行っている.ささらに，医学部 生の病棟実習に際しては, 彼らが将来, 感染症診療にお いて無知に基づく安易な判断をしないように（診断なし に広域抗菌薬を投与するなど), 微生物や抗微生物薬の レクチャー, AST ミーティングにおける議論への参加, あるいは病棟において手指衛生を実演してもらうなど, 「理論と実際」をバランス良く経験してもらえるように 心掛けている（図 1)。

\section{（ハ）血液培養に関する活動}

正しい診断を導くためには正しい培養検体の提出が重 要である，血液培養に関して，従来当院では皮膚消毒薬 としてイソジンが使用されていた。 しかし，特に高度救 命救急センターでは一刻を争う処置が必要な場面で, イ ソジンが十分に乾くまで待ち切れずにカテーテルが挿入 されるケースが多く, 污染（コンタミ）率が高かった. この点に関して, 消毒薬として $1 \%$ クロルヘキシジング ルコン酸塩 $(\mathrm{CHG})$ エタノール液の方が優れているこ とが報告されている年，我々も2017年 10 月より $1 \%$ CHG エタノール綿棒の院内採用を決定し, 徐々に使用 適応を拡大し, リンクナース会などを通して, CHG エ タノール消毒を周知したところ, CHG 消毒が浸透する につれてコンタミ率の減少傾向が認められた（図 2). 正しい培養結果が適切な治療薬選択につながることによ り AMR アクションプラン増進に寄与する一例として挙 げられる。

しかしながら，それでもなお抗菌薬投与前の培養ワー クアップが不十分なケースは見受けられる，例えば，高 度救命救急センターでは, ほほ血培実施後に届出制の対 象となる抗菌薬を開始しており（血培未実施率約 8\%), 後で最適化が図れるような努力がなされている，他方， 

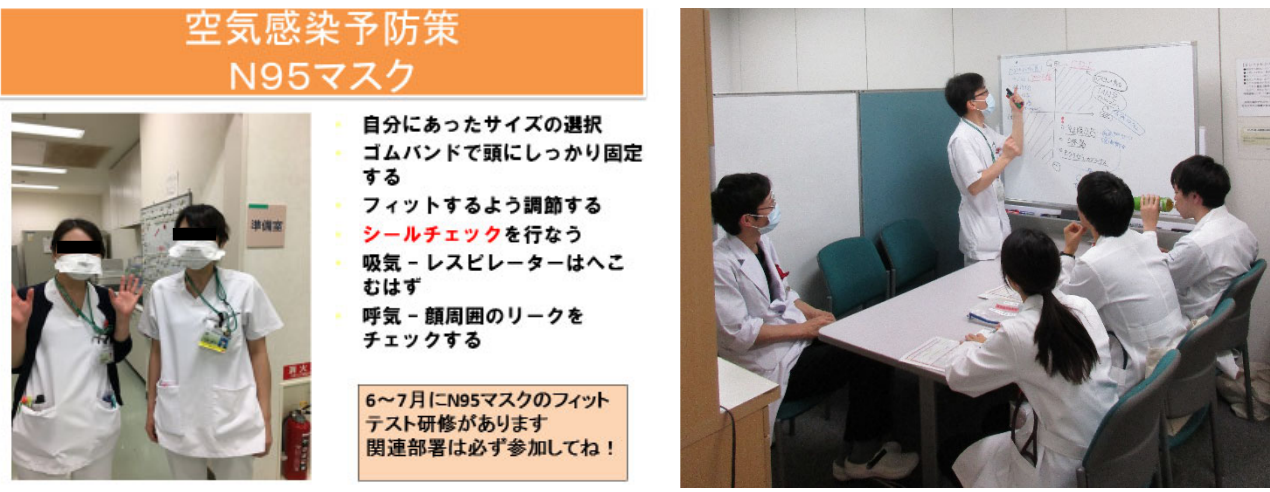

\section{接触感染予防策}
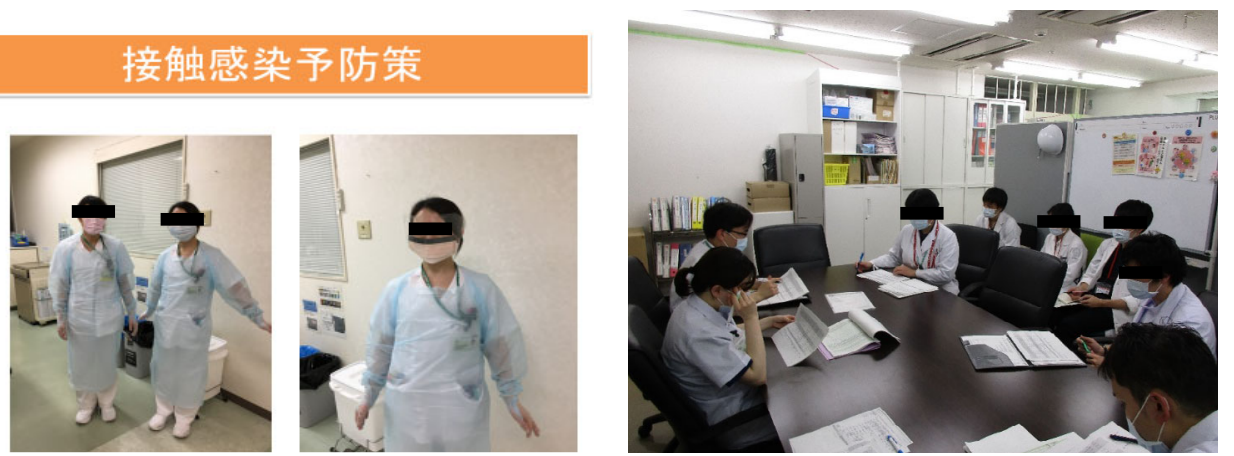

図 1 若手への教育・次世代人材育成

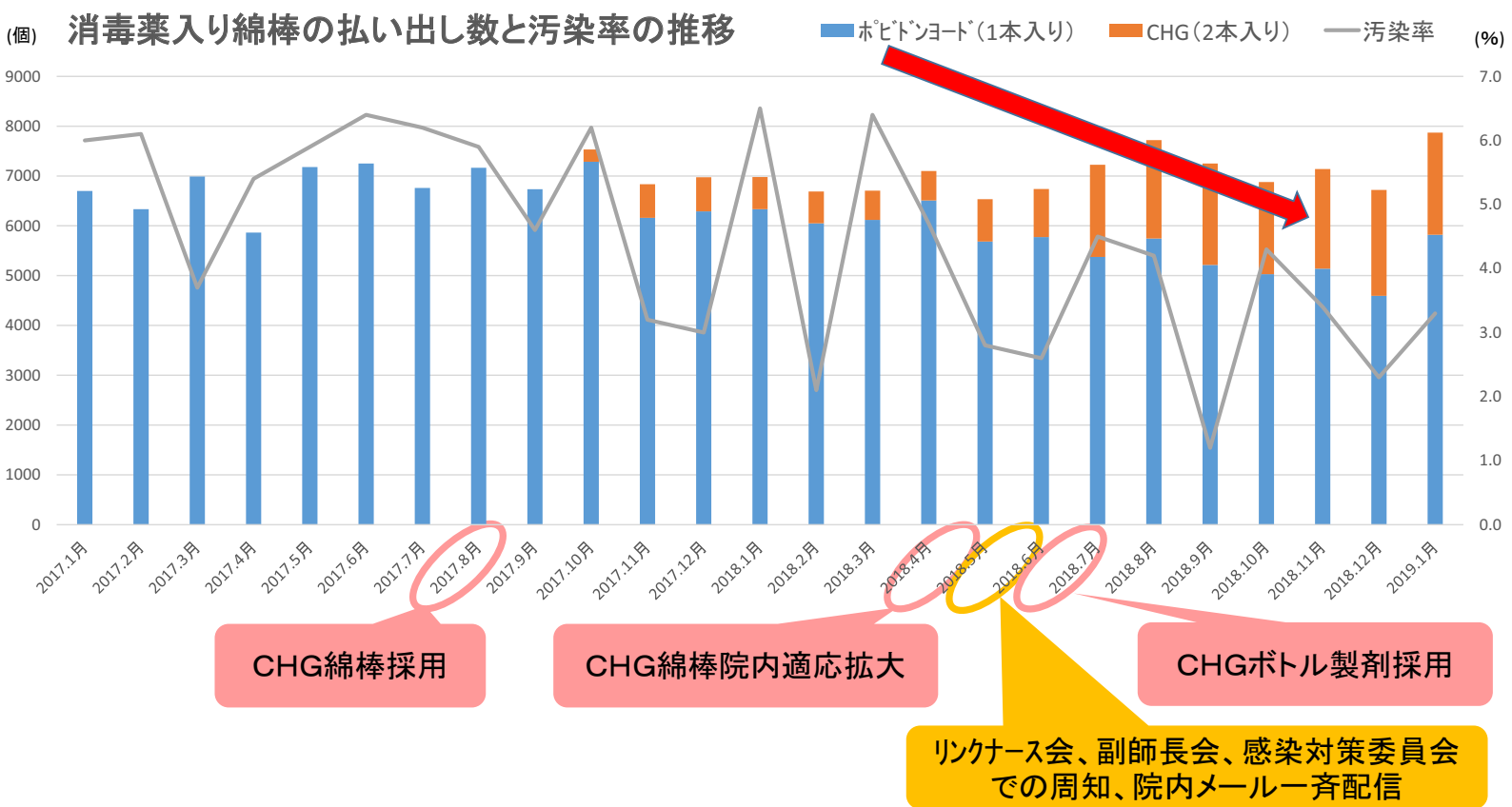

図 2 血培時の 1\%CHG エタノール使用と污染率低下

対象数が救命センターと同等にもかかわらず，培養ワー クアップしないまま広域抗菌薬を開始する傾向の強い診 療科も複数ある（図 3)。このように診療科間の差異が あり，我々は血培未実施率の高い診療科を重点的にラウ ンドの対象としていくなどの対策を立てている.

さらに実際に血培陽性症例については判明時より，毎
日, 主治医と並走してフォローすることが重要である (血 培ラウンド)。血培陽性例では, 主治医に速やかに伝え ることで重症化を阻止できる上，主治医とのコミュニ ケーションを取りやすくなり, 選択薬の提案などの介入 が容易となる利点がある。 また，若手医師への教育効果 も高い（図4).とりわけカンジダ菌血症に代表される 


\begin{tabular}{|c|c|c|c|}
\hline \multicolumn{4}{|l|}{ 検索期間 : 2018.04-2018.11 } \\
\hline 診療科 & 総対象数 & 血培未の総数 & 未/総数の割合 \\
\hline 血液内科 & 317 & 43 & 0.135646688 \\
\hline 消化器病センター & 314 & 68 & 0.21656051 \\
\hline 高度救命救急センター & 196 & 16 & 0.081632653 \\
\hline 心臓血管センター & 161 & 17 & 0.105590062 \\
\hline 呼吸器病センター & 139 & 4 & 0.028776978 \\
\hline 整形外科 & 48 & 13 & 0.270833333 \\
\hline リウマチ膠原病センター & 44 & 6 & 0.136363636 \\
\hline 泌尿器·腎移植科 & 41 & 7 & 0.170731707 \\
\hline 腎臓·高血圧内科 & 38 & 2 & 0.052631579 \\
\hline 炎症性腸疾患IBDセンター & 33 & 5 & 0.151515152 \\
\hline 神経内科 & 29 & 4 & 0.137931034 \\
\hline 皮膚科 & 20 & 6 & 0.3 \\
\hline 婦人科 & 17 & 3 & 0.176470588 \\
\hline 形成外科 & 17 & 2 & 0.117647059 \\
\hline 精神医療センター & 15 & 0 & 0 \\
\hline 総合周産期母子医療センター & 9 & 0 & 0 \\
\hline 乳腺-甲状腺外科 & 7 & 3 & 0.428571429 \\
\hline 内分泌 - 糖尿病内科 & 7 & 0 & 0 \\
\hline 脳神経外科 & 6 & 1 & 0.166666667 \\
\hline 眼科 & 6 & 6 & 1 \\
\hline 耳鼻咽喉科 & 4 & 2 & 0.5 \\
\hline 歯科口腔外科 & 2 & 0 & 0 \\
\hline
\end{tabular}

図 3 診療科別届出抗菌薬使用前の血培未実施率

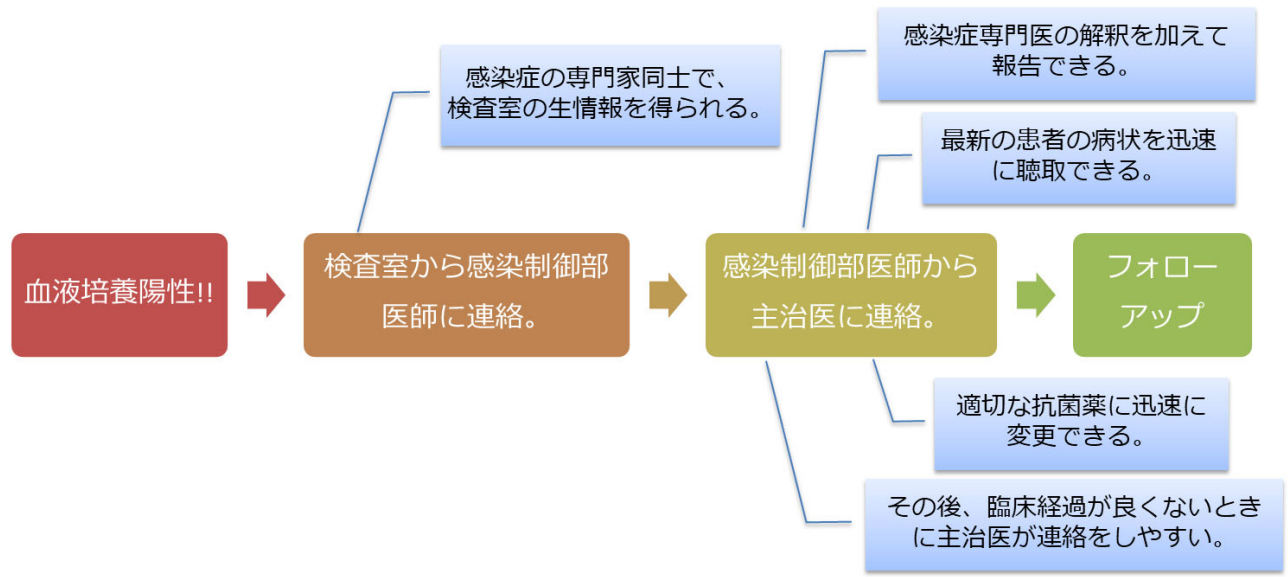

図 4 血液培養ラウンドの模式図

深在性真菌症の場合は一般細菌感染症に比較すると予後 不良であり，抗真菌薬を過剰に投与されるケースも少な くない. 最近, 一般抗菌薬だけではなく抗真菌薬の適正 使用や真菌感染症のマネージメントに関する診療支援の 取り組みが注目されている ${ }^{4)}$. 当院では日々の血培ラウ ンドにおいて, 酵母様真菌として検出された初期の段階 で, 電子カルテ記載と担当医への電話連絡を直接行って いる，治療薬の選択は，Candida albicans に代表される
アゾール系薬剤に対して感性なものなのか耐性の nonalbicans カンジダ属なのかで大きく異なり, 感染藏器へ の移行性も十分に考慮されなければならない.さらに, 深在性真菌症の診断・治療のガイドラインで提唱されて いる Bundle に記載された遵守項目 ${ }^{5}$ をすべて迅速に実 行することが重要であるが, 多忙な診療科医が Bundle 遵守項目を，スピーディーに全部こなすのは現実的には 非常に難しい。例えば，当該診療科が眼科受診の予約が 


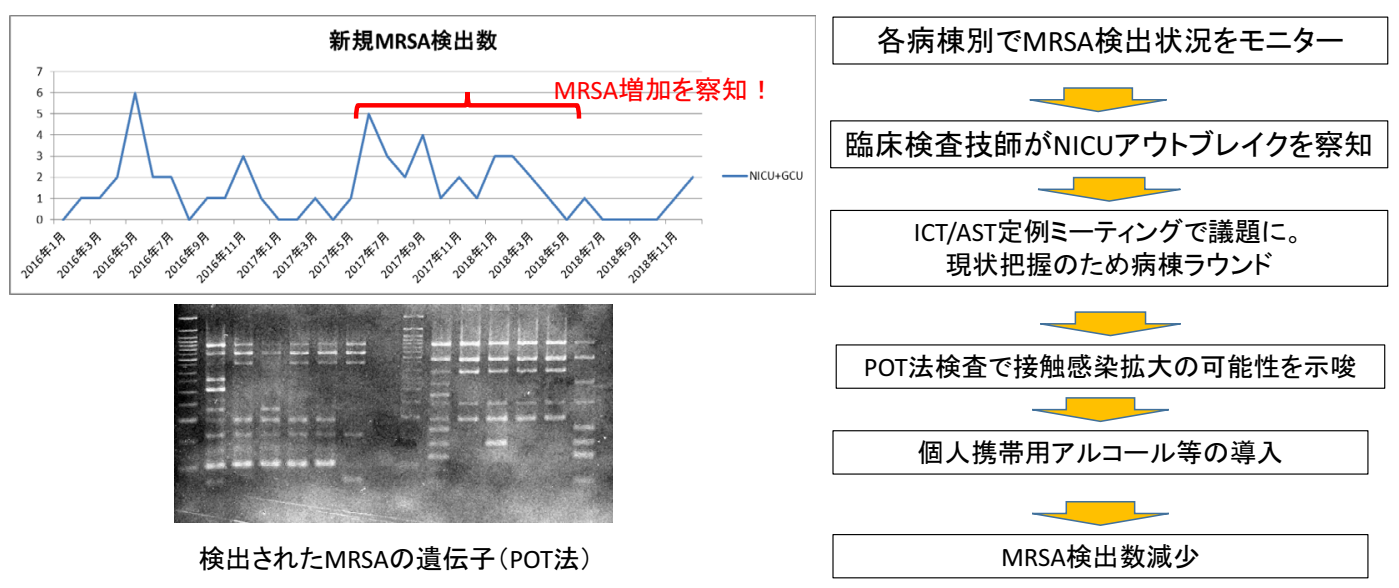

図 5 臨床検査技師による耐性菌アウトブレイク察知例

取れず，速やかな診察ができないケースや，逆に診察さ れても初診のみで終了とされてしまうケースがしばしば 見受けられる。そこで, 我々も診療科と共にカンジダ菌 血症例のモニターを行い, 診療科と眼科との間でうまく コミュニケートできていないケースを発見した場合は, 両者の間をとりもつ橋渡し役をしばしば演じている.

\section{（2）動向調査・監視（サーベイランス＆モニタリング）}

薬剂耐性および抗微生物薬の使用量の継続的モニター により薬剤耐性の変化・拡大の兆候を把握することであ る. 我々も院内感染対策委員会において, 薬剤師による AUD 算出報告, 臨床検査技師により耐性菌（MRSA, $\mathrm{ESBL}, \mathrm{CRE}, \mathrm{CDI}$ 等) の動向報告などを行っている. 報告のためのデー夕集積段階でアウトブレイクが疑われ る場合は当該部署をラウンドして現状を把握している.

具体例を挙げてみると, 周産期センターに属する NICU と GCU における MRSA 検出数の増加をモニター していた臨床検査技師が AST ミーティングで耐性菌検 出状況を報告するなかで問題を提起し, 病棟ラウンドを 行い, 接触予防策の不十分さが眯念され, POT 法で評 価したところ遺伝子パターンが一致し，接触感染予防策 の破綻が露呈された事例があった，当院では当時導入さ れていなかった個人携帯用アルコールの導入を, NICU と GCU の師長, 新生児科医師と感染制御部で話し合い の上で決定し実施したところ, MRSA 検出数は減少し 終息した．現在では，これらの病棟の医師・看護師は携 帯型を常時身に着けている（図 5).

ところが, その後のモニターで再び MRSA 検出率は 上昇傾向に転じた。 スタッフにインタビューしたところ, 携帯型は重い, 使いづらい, などと予想外に評判が悪く, 対策を見直してオートディスペンサー式手指消毒剤も導 入したところ評判も上がり MRSA 検出率も再び低下し た。

\section{（3）感染管理・予防}

（イ）薬剤耐性感染症の集団発生に対する対応能力の 強化

院内における思わぬ感染症集団発生, すなわちアウト ブレイクが起きてしまった場合の対応における要諦は, 関係者間の迅速な情報共有, 患者の隔離と接触者の特定, 検査体制の確立と確実な診断, 病原体により可能な場合 は抗微生物薬の予防投与・緊急ワクチン接種の検討およ び対策チームの結成, 保健所をはじめ行政との連携強化 などが挙げられる.

当院でも平成 29 年にバンコマイシン耐性腸球菌 （VRE）のアウトブレイクが発生したが，事前に横浜市 近接自治体病院および横浜市南部でVREアウトブレイ ク先行事例の情報を収集していた。これにより，例えば， 院内への持ち込みを想定して事前作成しておいた患者用 説明文を配布し，主治医から患者および家族への説明時 に活用してもらい，当該患者の隔離や病棟におけるスク リーニング実施にあたり大変有用であった．さらに当該 病棟の看護師・診療科医師を集めて VRE に関する説明 会を行い, 清掃委託責任者への入室方法や順序, 清掃用 具の専有化等を指示, 発生病棟での手すり・ドアノブの アルコール清拭 (1日1回), さらに, 全職員に対して 標準予防策の周知徹底の呼びかけを一斉配信するなどの 策を講じた結果，医療スタッフにも患者にも特段の混乱 は起きず，短期間で終息した。

さらに，これらの経験を踏まえて，発生時対応に関す る感染対策マニュアルの改訂を行い, 将来に向けた体制 強化に繋げることも忘れてはならない.

\section{（口）医療・介護における感染予防・管理と地域連携 の推進}

地域における感染予防・管理の一体的な取り組みとし て，(1）感染加算の連携会議の機会を利用した耐性菌対 策の情報交換，（2）YKB（横浜感染防止）と呼ばれる 横浜地区の多くの基幹病院が参加するネットワークにお 

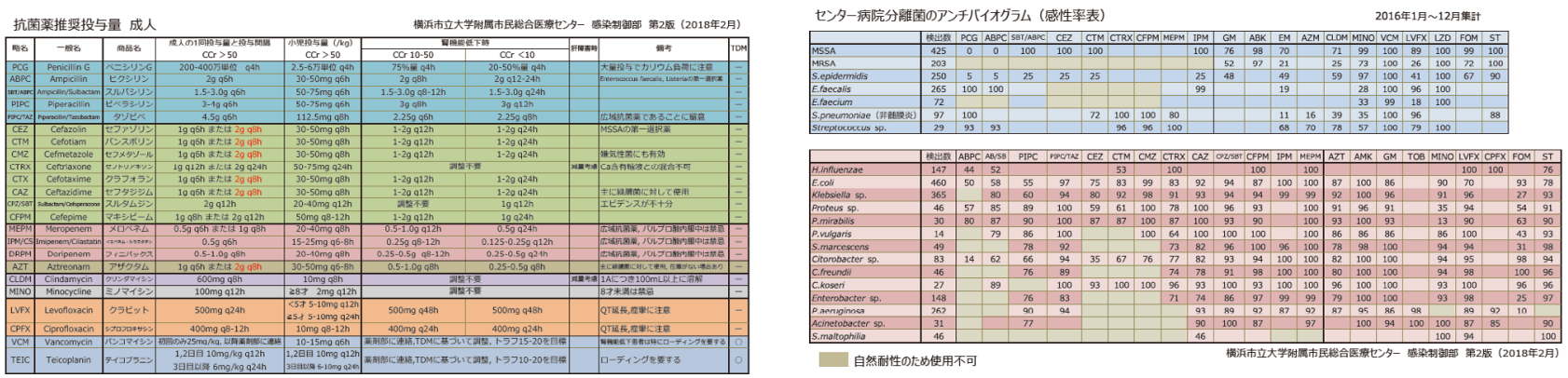

図 6 抗菌薬ポケットガイドの頒布

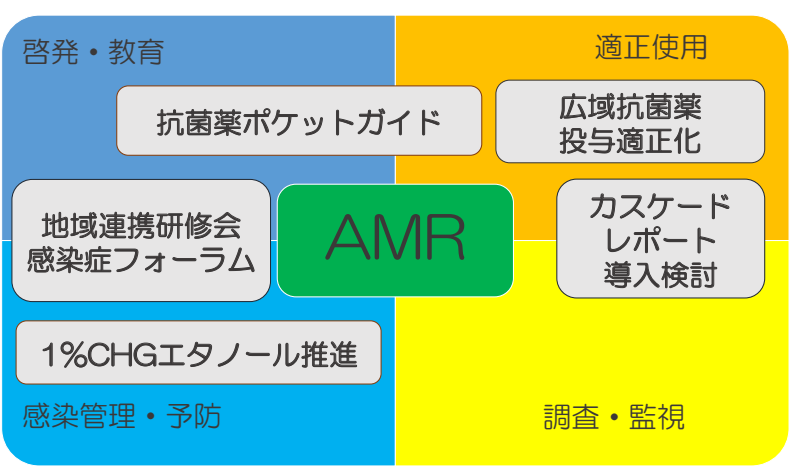

図 7 あと 1 年となった AMR アクションプランの取り組み

ける情報収集・提供，などが挙げられるが，通年で最も 頻繁に組織的コミュニケートしているのは，（3）保健所 (我々の地域においては横浜市南区福祉保健センター)で ある.VRE，結核などに関する横浜地区の検出状沉や 対策について頻繁に情報交換できる良き相談相手でもあ る.さらに，(4）医師会と密にコミュニケートすること により感染症の診断・治療・予防策の共通認識をあらか じめ醉成しておくことも感染対策を推し進める上で有用 である. 地区医師会に赴いての講演や，逆に地区医師会 との共催で感染症講演会を院内で隔月開催するなどによ り関係強化を図っている. 毎回テーマを変えて, 著名な 講師陣に講演していただくことで近隣の病院からも多数 の参加者があり, 影響力は大きい.

\section{（4）抗微生物薬の適正使用}

本論文の骨子は AS 以外の実践についてであるが，実 際の現場では非感染症医が抗菌薬（抗微生物薬）を十分 に使いこなせないが故に, AST 活動におけるASの比 率は非常に高いのが現実である。そこでASにおける抗 菌薬適正使用を推進するための我々の工夫を一つ紹介す る。診療科抢よび薬剤部（AST に直接関与していない 薬剤師）と巧みにコミュニケートするために，2016 年 度より『抗菌薬ポケットガイド』の頒布を開始した。こ れは白衣の胸ポケットに収まる大きさ $(80 \mathrm{~mm} \times 160$ mm）のラミネートされたカードである. 実際は, (1)成
人量（診療科医師用）（図 6), (2)成人量（感染制御部\& 薬剂部用), (3)小児量用, の計 3 バージョンを作成し, 紙 媒体だけではなく電子カルテ上でも閲覧可能とした。 (2) も作成したのは薬剤部と感染制御部の間で推奖内容の歒 龉をきたさぬための配慮である。このガイドの頒布によ り，片手で院内 PHS で会話しながら，もう一方の手で 容易に抗菌薬の 1 回使用量・投与間隔が腎機能別に確認 できるもので利便性が高く, 他の病院からの頒布要望の 照会が相次ぐ事態となり, 我々としては望外の喜びで あった。

\section{最 後 に}

AMR アクションプランの成果目標達成のための期間 は残すところあと 1 年となった。冒頭で述べたように, 今般の抗菌薬の供給制限（出荷調整）による混乱が長期 化・深刻化するという逆風にさらされている状況下であ るが, 耐性菌出現抑制対策をさらに前進させるために, 安易に広域抗菌スペクトラムを有する抗菌薬を診療医に 選択させず，自然に元来の第一選択薬を選択されるよう に, 細菌培養検查結果の報告書を診療科に送り返す際の 工夫（カスケード・レポート ${ }^{6}$ の導入など）も検討して いる(図 7).

\section{利益相反自己申告：申告すべきものなし．}

\section{文献}

1）国際的に劦威となる感染症対策関係閣僚会議：薬剂耐性 (AMR) 対策アクションプラン $2016: \mathrm{https} / /$ www.mhlw. go.jp/stf/seisakunitsuite/bunya/0000120172.html : 2020 年 1 月 8 日現在

2) Mimoz O, Karim A, Mercat A, Cosseron M, Falissard B, Parker F, et al: Chlorhexidine compared with povidoneiodine as skin preparation before blood culture. A randomized, controlled trial. Ann Intern Med 1999; 131(11): 834-7.

3）大手裕之, 須垣佳子, 西川佳友, 南 仁哲, 川端 厚 : $1 \%$ クロルヘキシジンアルコール皮虐消毒による血液培養の污 染率に与える影響の評価. 感染症学雑誌 2018; 92: 46-50.

4) 掛屋 弘, 山田康一, 川口博資：院内に扔ける Antifungal Stewardship（AFS）への取り組み。感染と抗菌薬 2018; 21(2): 149-58.

5）深在性真菌症のガイドライン作成委員会編：深在性真菌症 
の診断・治療ガイドライン 2014, 協和企画

6) Johnson LS, Patel D, King EA, Maslow JN: Impact of microbiology cascade reporting on antibiotic de-escalation in cefazolin-susceptible Gram-negative bacteria. Eur J Clin Microbiol Infect Dis 2016; 35: 1151-7.
〔連絡先：戸232-0024 横浜市南区浦舟町 4-57

横浜市立大学附属市民総合医療センター感染制御部 築地 淳

E-mail: tsukijij@yokohama-cu.ac.jp]

\title{
Well-balanced Practice of the AMR Action Plan in Yokohama City University Medical Center
}

\author{
Jun Tsukiji ${ }^{1}$, Haruyo KAWAharA ${ }^{1)}$, Ryoko HigA ${ }^{1}$, , Yoshifumi SugiYama ${ }^{1}$, \\ Kaori TsujITA $^{1)}$, Saori KIDA ${ }^{1}$, Soichiro SugIYAMA ${ }^{1)}$ and Hiroyuki SHIMIZU' ${ }^{1,2)}$ \\ 1) Department of Prevention and Infection Control, Yokohama City University Medical Center, \\ ${ }^{2)}$ Department of Clinical Laboratory Medicine, Fujisawa City Hospital
}

\begin{abstract}
Issues of antimicrobial-resistant (AMR) bacteria are a serious problem to tackle the global health crisis, which drove the government to formulate the National Action Plan on AMR to change this situation for the better until 2020 in Japan. The plan consists of themes such as education and enlightenment, surveillance and monitoring, prevention and infection control, promotion of the proper use of antimicrobial agents, and so on. We present our concrete examples of the practice in each theme of the AMR action plan in our hospital, Yokohama City University Medical Center.
\end{abstract}

Key words: antimicrobial resistance, AMR, AMR action plan 